\title{
General Movement Assessment, czyli Ocena Globalnych Wzorców Ruchowych wg Prechtla - teoretyczny opis metody diagnostycznej dziecka ryzyka zaburzeń rozwojowych
}

\section{General Movement Assessment - a theoretical description of a diagnostic approach to an at-risk infant}

\author{
Michał Sokotów (iD),Ewa Pilarska* (iD) \\ Ośrodek Wczesnej Interwencji Gdańsk, Klinika Neurologii Rozwojowej Gdański Uniwersytet Medyczny \\ *Klinika Neurologii Rozwojowej Gdański Uniwersytet Medyczny \\ DOI:10.20966/chn.2020.59.473
}

\section{STRESZCZENIE}

Rozwój strukturalny ośrodkowego układu nerwowego przebiega w sposób najbardziej intensywny w pierwszych latach życia. Działanie niekorzystnych zmiennych tzw. czynników ryzyka zaburzeń rozwojowych, zwłaszcza w okresie ciąży, może doprowadzić do różnorodnych zaburzeń naturalnego procesu ksztattowania się mapy neuronalnej.

Istnieje wiele narzędzi, pozwalających na ocenę trajektorii rozwojowej niemowlęcia. Jednym z najbardziej skutecznych jest Metoda Prechtla, znana jako General Movement Assessment, która opiera się na analizie jakościowej motoryki spontanicznej dziecka- tzw. ruchów globalnych.

Ruchy globalne (GMs) to złożona sekwencja motoryczna, obecna w obrębie kończyn górnych, dolnych, szyi i tułowia. Manifestuje się ze zmienną intensywnością, siłą oraz prędkością. Ma wyraźny początek, i stopniowo narasta, by w końcu zniknąć w pojedynczym cyklu. Charakter GMs, ze względu na obecność rotacji i różnokierunkowość, można określić, jako płynny, harmonijny, elegancki. GMs pojawiają się w motoryce dziecka między 9 a 12 tygodniem życia wieku post-menstrualnego (PMA) i utrzymują się w podobnej formie do 46- 49 tygodnia PMA. Niniejszy artykuł przybliża obraz General Movement Assessment w kontekście dziecka ryzyka zaburzeń rozwojowych. Podkreśla wiarygodność tego podejścia diagnostycznego i ukazuje jego znaczenia dla kontroli procesu usprawniania fizjoterapeutycznego.

Słowa kluczowe: Metoda Prechtla, General Movement Assessment, dziecko ryzyka, diagnostyka niemowlęcia, Mózgowe Porażenie Dziecięce.

\section{ABSTRACT}

Structural development of the Central Nervous System is most intensive during the first years of life. Influence of detrimental variables, known as "risk factors" especially during pregnan$c y$, can lead to various complications of the natural neural map shaping.

There are many tools available to assess an infant's developmental trajectory. One of the most valuable is the Prechtl's General Movement Assessment. The basis for this approach is build upon the qualitative analysis of the infant's spontaneous motility, the so- called general movements.

General Movements (GMs) are complex motor sequences present in upper and lower extremities, around neck and trunkmanifested with variable intensity, force and speed. They have a vivid starting point, then gradually increase in intensity to finally cease in a single cycle. The character of GMs is fluent, elegant and harmonious due to rotational component and changes in the directions of the movement. GMs can be observed in infants motor repertoire between 9 to 12 weeks of post- menstrual age (PMA) and last up to 46- 49 weeks of PMA

This article presents the overall picture of General Movement Assessment in the context of an at- risk child. It supports the validity of the method and reveals its significance as a control mean of a physiotherapeutic process.

Key words: Pechtl's method, General Movement Assessment, at-risk child, infant diagnostics, cerebral palsy

\section{WSTĘP}

Rozwój strukturalny ośrodkowego układu nerwowego odbywa się przez cały okres życia płodowego i trwa wiele lat po urodzeniu, do zakończenia mielinizacji korowych włókien kojarzeniowych i włókien istoty szarej.

W poszczególnych okresach rozwoju dziecka tj. w okresie prenatalnym, perinatalnym i postnatalnym mogą wystąpić czynniki szkodliwe prowadzące do zaburzenia w jego rozwoju.

Okres prenatalny jest jednym z najbardziej istotnych dla prawidłowego rozwoju dziecka. Do istotnych czynników uszkodzenia ośrodkowego układu nerwowego (OUN) $\mathrm{w}$ okresie prenatalnym należą: przewlekle choroby matki (serca, płuc, nerek, padaczka), stany niedoboru ilościowe (niedożywienie), jakościowe (niedobór witamin), niedokrwistość, komplikacje ciążowe (zagrażające poronienie, zatrucie ciążowe- EPH- gestozy a także wysokie miano przeciwciał w wyniku niezgodności czynnika RH, zaburzenia związane $\mathrm{z}$ łożyskiem np. łożysko przodujące, odklejanie się łożyska. Infekcje wirusowe (różyczka, cytomegalia, opryszczka, ospa wietrzna, półpasiec, grypa), infekcje bakteryjne (listerioza, kiła) oraz pasożytnicze (toksoplazmoza). Nie bez znaczenia jest obecność środków zaliczanych do chemicznych jak: alkohol, nikotyna, narkotyki, związki rtęci, ołowiu. 
Do czynników działających w okresie okołoporodowym zalicza się m.in.: zamartwicę i niedotlenienie płodu, przedwczesne odejście wód płodowych, wahania lub zwolnienia akcji serca płodu. Do czynników działających w okresie poporodowym mogących mieć wpływ na dalszy rozwój dziecka zalicza się przede wszystkim: zakażenie dróg oddechowych, zapalenie opon mózgowo rdzeniowych lub mózgu [1].

W ostatnich kilku dekadach, obserwuje się znaczący wzrost poziomu wielospecjalistycznej opieki nad dzieckiem ryzyka zaburzeń rozwojowych. Zarówno przeżywalność, jak i jakość życia dla tej grupy pacjentów nieustannie wzrastają.

Następstwem działania czynników szkodliwych na OUN jest opóźnienie rozwoju psychoruchowego, mózgowe porażenie dziecięce, niepełnosprawność intelektualna, całościowe zaburzenia rozwoju, zaburzenia funkcji poznawczych, emocjonalne i inne [2].

Wobec tych zagrożeń istotnym staje się szybkie, prawidłowe, precyzyjne rozpoznanie i zastosowanie właściwej terapii. Wśród narzędzi dostępnych specjalistom wymienia się tradycyjne badanie kliniczne, metody neuroobrazowania, głównie ultrasonografia mózgu i rezonans magnetyczny, a także usystematyzowane metody oceny rozwoju dziecka, z których największą skuteczność demonstrują General Movement Assessment (Metoda Prechtla) i Hammersmith Infant Neurological Exam (HINE).

Heinz Friedrich Rudolf Prechtl był znakomitym austriackim badaczem, lekarzem, zoologiem i antropologiem. Jako pierwszy zaobserwował specyficzne wzorce ruchowe w zachowaniu płodu i okresie wczesnego dzieciństwa.

\section{GENERAL MOVEMENT ASSESSMENT}

Wg Profesora Heinza Prechtla, idealna metoda neurologicznej oceny noworodka powinna być nieinwazyjna, nie czasochłonna, wysoce czuła i swoista w określaniu stanu dziecka [3]. Na podstawie długoletnich obserwacji, Profesor Prechtl zdołał opisać kilka wzorców spontanicznej motoryki noworodka i niemowlęcia, które w zależności od formy, pozwalają na bardzo dokładne przewidywanie ostatecznego poziomu funkcjonalnego. Tak zwane General Movements (GMs) to złożone, globalne ruchy, obecne naprzemiennie w każdym segmencie ciała [3-4]. Odkrycie General Movements doprowadziło do powstania Oceny Globalnych Wzorców Ruchowych wg Prechtla (GMA) [5], metody określającej integralność układu nerwowego dziecka, w wieku do około 20 tygodnia wieku życia (60 tygodni wieku post-menstrualnego).

\section{Prawidłowe General Movements:}

Ruchy GMs powstają przez aktywność zagęszczonej sieci neuronów, określanych jako Centralny Generator Wzorca (CPG), zlokalizowanej najprawdopodobniej w okolicy pnia mózgu [6]. Centralne Generatory Wzorca odpowiadają za obecność rytmicznych zachowań ruchowych takich jak chodzenie, ssanie, oddychanie [7]. Motoryka ta nie jest wynikiem stymulacji zewnętrznej- powstaje endogennie. Profesor Prechtl używał pojęcia Centralnego Generatora Wzorca również w stosunku do ruchu obserwowanego u płodu, takich jak ziewanie, przeciąganie się i GMs. Wzorce ruchowe tego okresu są powtarzalne, występują z regularnością i łatwo je opisać- spełniają więc kryteria aktywności spowodowanej przez Centralny Generator Wzorca. W ruchach typu GMs efekt różnorodności i złożoności jest wynikiem modulacji z ośrodków nadrdzeniowych nałożonej na aktywność z CPG. Podobny rezultat przynosi również stymulacja eksteroreceptywna [6]. Rycina numer 1 . schematycznie opisuje te zależności.

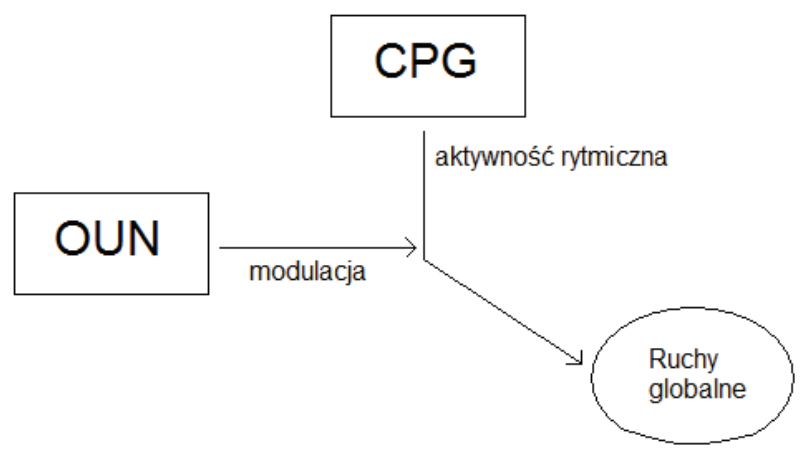

Ryc. 1 Modulacja rytmicznej aktywności CPG nadaje motoryce GMs różnorodny, złożony charakter

Fig. 1 Modulation of the rhythmic activity of CPG gives the GM motorization a diverse and complex character

Prawidłowe GMs to złożona sekwencja ruchów, obecna w obrębie kończyn górnych, dolnych, szyi i tułowia. Manifestuje się ze zmienną intensywnością, siłą oraz prędkością. Ma wyraźny początek, i stopniowo narasta, by w końcu zniknąć w pojedynczym cyklu. Charakter GMs, ze względu na obecność rotacji i różnokierunkowość, można określić, jako płynny, harmonijny, elegancki. Obserwujący ma wrażenie złożoności i różnorodności ruchu. GMs pojawiają się w motoryce dziecka między 9 a 12 tygodniem życia wieku post-menstrualnego (PMA) i utrzymują się w podobnej formie do 46- 49 tygodnia PMA. Niezależnie od faktu, czy dziecko urodziło się o czasie, czy też przedwcześnie- w fizjologicznych warunkach- czasookres występowania GMs jest taki sam [3]. Co prawda, GMs dziecka urodzonego przedwcześnie mogą mieć większą amplitudę i prędkość. Różnice te nie są jednak znaczne, co wskazuje na prawidłowość, że zarówno zwiększenie siły grawitacji, jak i dojrzewanie OUNdo 40 tygodnia ciąży- nie mają wpływu na występowanie GMs [8-9]. W celu rozróżnienia, motorykę spontaniczną wcześniaka określa się jako ruchy wcześniacze, natomiast po 40 tygodniu, do 46-49 tygodnia PMA- używa się terminu ruchów wijących (ang.writhing movements) [5].

W wieku między 6 a 9 tygodniem wieku post-urodzeniowego, writhing movements zaczynają wygasać i stopniowo pojawia się inna forma spontanicznej motoryki globalnej tzw. ruchy drobnookrężne, czy też fidgety movemets (FMs), która będzie kontynuowana aż do 5 miesiąca życia dziecka (z uwzględnieniem korekcji wieku u wcześniaków) (ryc. 2). FMs będą zauważalne u niemowlęcia podczas czu- 
wania (dla porównania - writhing movments występują również podczas snu) w okolicy wszystkich kończyn, szyi i tułowia. Idealnym stanem do przeprowadzenia obserwacji jest 4 wg skali Brazeltona. FMs mają mniejszą amplitudę, średnią prędkość i zmienne przyspieszenie. Eksponowane są w różnych kierunkach [10-11]. Czasowa organizacja FMs zmienia się z wiekiem. Początkowo występują jako pojedyncze elementy, narastają w częstotliwości i w końcu wygasają koło 16-20 tygodnia życia. Szczyt intensywności motoryki FMs przypada na 12-16 tydzień życia dziecka. W rozwoju typowym FMs możemy podzielić na prawidłowe/ ciągłe $(\mathrm{F}++)$ lub przerywane $(\mathrm{F}+)$ [11-15]. Profesor Prechtl uważał, że FMs są wynikiem prawidłowej pracy układu proprioceptywnego niemowlęcia [16]. W okresie ruchów FMs, niemowlę będzie również korzystać z innych aktywności. Zaobserwujemy min. oscylacyjne ruchy kończyn górnych, manipulację, pracę antygrawitacyjną ramion i nóg. Po 5 miesiącu życia- motoryka celowa będzie głównym zbiorem zachowań dziecka.

zmieniać w konsekwencji uszkodzenia tych struktur [10]. Krwawienia do OUN oraz zmiany leukomalacyjne zaburzają więc modulację rytmicznych wyładowań z Centralnego Generatora Wzorca, prowadząc do wystąpienia nieprawidłowych GMs. Uszkodzenie OUN powoduje, że GMs tracą swój różnorodny, wielowymiarowy charakter. W tym wypadku dziecko, w wieku do 6- 9 tygodnia wieku post-urodzeniowego, może manifestować motorykę ty$\mathrm{pu}$ poor repertoire (PR), cramped- synchronized (CS) lub chaotic (Ch).

Motoryka PR jest bardziej monotonna w porównaniu do prawidłowych GMs. Ponadto, opisuje się ją jako powtarzalną, mniej złożoną i występującą w sposób przerywany. Zaburzeniu ulega także płynność ruchu. PR najczęściej dotyczy dzieci urodzonych przedwcześnie, bez znacznych zmian w USG [6]. Wartość prognostyczna PR jest niewielka, ponieważ w późniejszym okresie, niemowlę może zarówno rozwijać się bez większych komplikacji jak i w sposób atypowy.
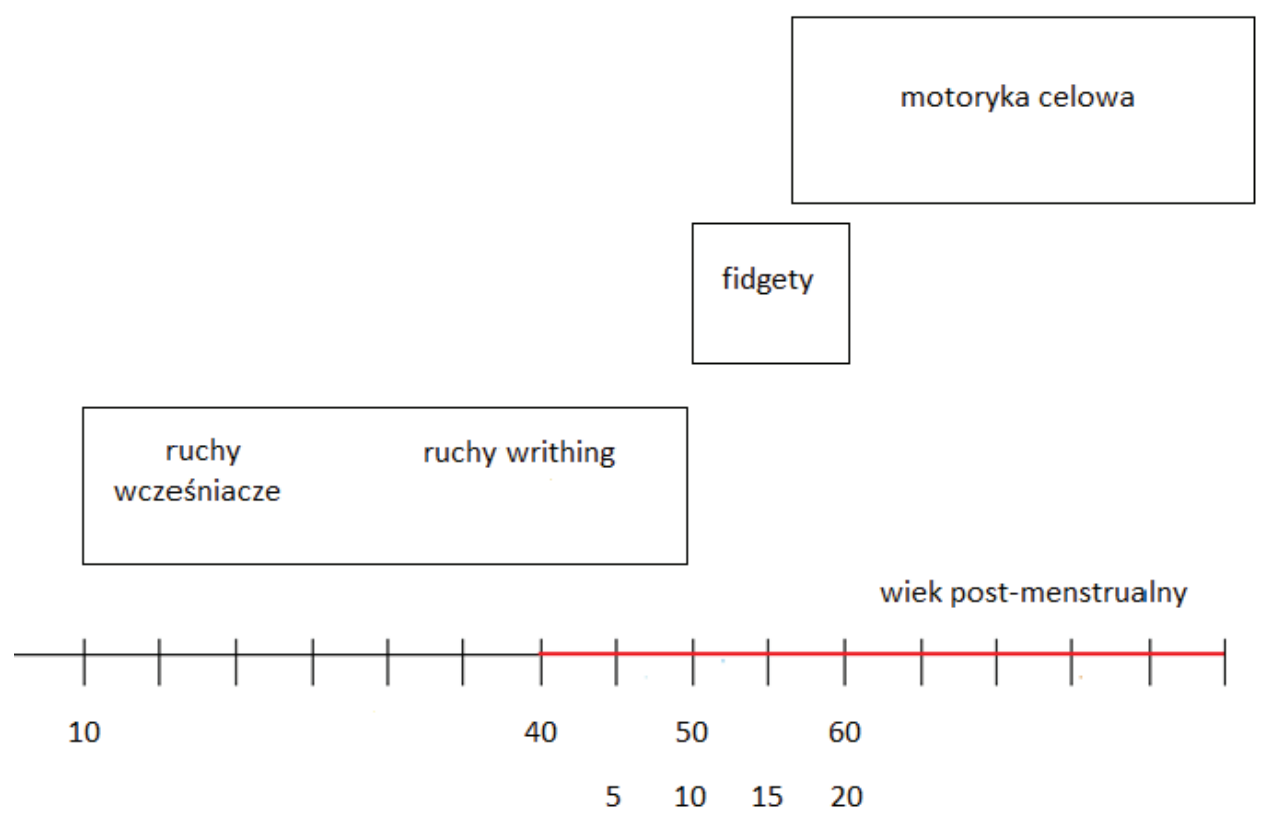

termin wiek post- urodzeniowy

Ryc. 2 Ruchy globalne w zależności od wieku dziecka

Fig. 2 Global movements depending on the age of the child

Mimo, iż definicja GMs jest złożona, każdy ze wzorców, w zależności od wieku, typowych bądź atypowych trajektorii rozwojowych, może być precyzyjnie opisany i wyodrębniony. Tabela I w skrócie podsumowuje prawidłowe GMs.

\section{Nieprawidłowe General Movements}

U niemowląt niskiego i wysokiego ryzyka zaburzeń rozwojowych, GMs nie różnią się pod kątem ilościowym, widoczne są jednak rozbieżności jakościowe. Jakość GMs jest najprawdopodobniej modulowana przez drogi korowo- rdzeniowe oraz siateczkowo- rdzeniowe i będzie się
Motoryka CS odznacza się brakiem różnorodności, płynności i złożoności. Można powiedzieć, że napięcie pojawia się równocześnie w wielu segmentach ciała. Utrzymujące się wzorce typu CS świadczą z dużym prawdopodobieństwem o rozwijanej spastycznej formie mózgowego porażenia dziecięcego [17]. Wcześniejsze wystąpienie i dłuższy czas utrzymywania się ruchów CS, rokuje większe problemy psychomotoryczne dziecka.

Motoryka Ch to sekwencja przebiegająca z dużą amplitudą, często w towarzystwie drżeń i w sposób urywany. W późniejszym czasie może ewoluować w kierunku ruchów CS. Występuje rzadko [4] 
Zaburzenia $\mathrm{w}$ obrębie OUN będą również, a nawet przede wszystkim, powiązane $\mathrm{z}$ prezentacją nieprawidłowych ruchów typu FMs. Istnieje szereg doniesień, które potwierdzają dużą czułość i swoistość oceny dziecka w wieku ruchów FMs i ich korelację z występowaniem późniejszych problemów neurologicznych [16, 18-19]. Brak występowania motoryki FMs (F-) między 9 a 20 tygodniem wieku post- urodzeniowego, wiąże się z istotnym prawdopodobieństwem (91-98\%) wystąpienia mózgowego porażenia dziecięcego. Ruchy FMs typu sporadycznego $(\mathrm{F}+/-)$ również mogą wiązać się z nieprawidłowościami rozwojowymi $[11,16,20]$. W tym wariancie FMs będą manifestowane przez niemowlę, ale w sposób mniej ekspresyjny. Z kolei nieprawidłowe ruchy FMs (AF) stanowią przeciwległy biegun obserwacji. Ich zwiększona amplituda, prędkość, powodują, że są przerysowane i nad- ekspresyjne. Wartość prognostyczna AF jest niska [5]. (Tab. I)

\section{Czas trwania oceny, procedura i obiektywność oceny}

Globalna, wzrokowa percepcja jakościowa ruchu (percepcja Gestalt) pozwala na rzetelne różnicowanie pomiędzy prawidłowymi i nieprawidłowymi GMs. Ewaluację wykonuje się najczęściej na podstawie nagrania video, jednakże ocena bezpośrednia (szczególnie w okresie występowania FMs) jest jak najbardziej możliwa i skuteczna [21]. Procedura nagrania zakłada pozycję leżącą na plecach dziecka, z odkrytymi ramionami i kończynami dolnymi, na jednolitym tle w swobodnym ubraniu. Przy ocenie ruchów FMs ważne jest, żeby niemowlę było obudzone, bez smoczka, nie płaczące. Należy też unikać interakcji ze strony obecnych osób. Dokładny opis wszystkich zmiennych potrzebnych do przeprowadzenia wystandaryzowanej oceny znajduje się w podręczniku Method on the Qualitative Assessment of General Movements in Preterm, Term and Young Infants [5].

Tab. I Prawidłowe i nieprawidłowe ruchyGM. Normal and abnormal GMs.

\begin{tabular}{|l|l|}
\hline $\begin{array}{l}\text { Prawidłowe GM } \\
\text { Normal GM }\end{array}$ \\
$\begin{array}{l}\text { Od } 9 \text { do } 49 \text { tygodnia PMA } \\
\text { From } 9 \text { to } 49 \text { week of PMA }\end{array}$ \\
\hline $\begin{array}{l}\text { Ruchy wcześniacze } \\
\text { Premature movements }\end{array}$ & $\begin{array}{l}\text { Stanowią wariant ruchów wijących, ale } \\
\text { przebiegają w większym zakresie, są bardziej } \\
\text { urywane, szczególnie w obrębie kończyn } \\
\text { dolnych. Charakteryzują się zmienną amplitudą } \\
\text { nieco większą prędkością, podobnym torem } \\
\text { przebiegu. }\end{array}$ \\
\hline $\begin{array}{l}\text { Ruchy wijące } \\
\text { Writhing movements }\end{array}$ & $\begin{array}{l}\text { Zmienna amplituda, prędkość wolna do } \\
\text { średniej, eliptyczna trajektoria ruchu kończyny } \\
\text { Głównie w płaszczyźnie strzałkowej z } \\
\text { elementami rotacji. Najłatwiejsze do } \\
\text { zauważenia w } 40 \text { tygodniu PMA }\end{array}$ \\
\hline
\end{tabular}

Od 46 do 64 tygodnia PMA

From 46 to 64 week of PMA

Ruchy fidgety

Fidgety movements

Mniejsze niż ruchy wijące, prędkość umiarkowana z okresowo pojawiającym się przyspieszeniem. Przebiegają we wszystkich kierunkach, widoczne w całym ciele, mają stały czas występowania. Do zaobserwowania u dziecka w stanie czuwania, nie płaczącego, nie skupionego na wybranym obiekcie.

Najłatwiejsze do zauważenia w 3 miesiącu życia (52 PMA)

\section{Nieprawidłowe GM \\ Abnormal GM}

Okres wcześniaczy i ruchów wijqcych

Premature and writhing movements period

Ubogi repertuar (PR)

Poor repertoire (PR)

Monotonna sekwencja, kilka prostych, powtarzających się elementów ruchowych. Czasami zaburzona płynność 


\begin{tabular}{|l|l|}
\hline $\begin{array}{l}\text { Ruchy kurczowo- zsynchronizowane (CS) } \\
\text { Cramped-synchronized movements (CS) }\end{array}$ & $\begin{array}{l}\text { Brak złożoności, płynności, różnorodności. } \\
\text { Kończyny (i tułów) napinają się i rozluźniają } \\
\text { niemalże równocześnie }\end{array}$ \\
\hline $\begin{array}{l}\text { Ruchy chaotyczne (Ch) } \\
\text { Chaotic movements (Ch) }\end{array}$ & $\begin{array}{l}\text { Duża amplituda, ruch urywany, drżácy. } \\
\text { Chaotyczna sekwencja bez płynności. } \\
\text { Występują rzadko, często zmieniają się w CS }\end{array}$ \\
\hline $\begin{array}{l}\text { Hypokinezja } \\
\text { Hypokinesia }\end{array}$ & $\begin{array}{l}\text { W czasie kilku godzin obserwacji brak lub } \\
\text { bardzo rzadko występujące ruchy GM. Bardzo } \\
\text { rzadko spotykane }\end{array}$ \\
\hline $\begin{array}{l}\text { Okres fidgety } \\
\text { Fidgety period }\end{array}$ & \multicolumn{2}{|l|}{} \\
\hline $\begin{array}{l}\text { Nieobecne fidgety (F-) } \\
\text { Absence of fidgety (F-) }\end{array}$ & Ruchy FM są niezauważalne podczas obserwacji \\
\hline $\begin{array}{l}\text { Nieprawidłowe fidgety (AF) } \\
\text { Abnormal fidgety }\end{array}$ & $\begin{array}{l}\text { Ruchy podobne do FM, ale z większą amplitudą, } \\
\text { prędkością i urywane. Ma się wrażenie } \\
\text { przesadzonej motoryki }\end{array}$ \\
\hline
\end{tabular}

Specjalista z doświadczeniem i po odpowiednim treningu potrzebuje od 1 do 3 minut na przeprowadzenie rzetelnego badania wg GMA. Należy jednak pamiętać, że dopiero kolekcja kilku nagrań, stworzonych w różnym wieku dziecka gwarantuje wysoką skuteczność oceny. W idealnych warunkach dąży się do uzyskania 2-3 nagrań z okresu ruchów wcześniaczych, 2 z okresu motoryki writhing i jednego z wieku FMs.

\section{Wartość prognostyczna GMA}

GMA jest metodą wysoce wiarygodną i spójną, dobrze wypadającą w badaniach określających zgodność pomiędzy kilkoma oceniającymi (inter- rater reliability) jak i pomiędzy kilkoma próbami oceny jednego dziecka (intra- rater reliability) [22-23].

W ostatniej dekadzie pojawiła się również wersja skomputeryzowana GMA, która wykazuje czułość na poziomie $85 \%$ i swoistość rzędu $88 \%$ w przewidywaniu rozwinięcia Mózgowego Porażenia Dziecięcego [24-25].

Mimo, iż nieobecność ruchów typu fidgety wykazuje silną korelację dodatnią z wystąpieniem objawów Mózgowego Porażenia Dziecięcego, na tej podstawie nie można określić, który typ tego zespołu niemowlę rozwija i jak bardzo będzie wymagało wsparcia otoczenia. Niemniej, istnieją pewne przesłanki, które mogą świadczyć o pojawieniu się oznak postaci hemiplegii lub postaci dyskinetycznej. W pierwszym przypadku, oprócz zanotowania motoryki typu CS, przed 9 tygodniem wieku post- urodzeniowego i brakiem fidgety (F-) w późniejszym okresie, zauważalne również powinny być asymetrie w zakresie ruchów segmantalnych [26-27], słabiej wyrażonych po stronie przeciwnej do ogniskowego uszkodzenia CUN. W postaci dyskinetycznej natomiast, w okresie do 9 tygodnia wieku post- urodzeniowego, za cechę charakterystyczną uważa się wystąpienie ruchów PR w kombinacji z powtarzalną, stereotypową, sekwencją ruchu kończyn górnych (lub jednej z nich) po szerokim okręgu, z jednoczesnym, przesadzonym rozkładaniem palców. W wieku późniejszym, takie dziecko, nie zademonstruje motoryki fidgety [28].

\section{Motor optimality score (MOS) na podstawie metody Prechtla}

Istnieją dwa arkusze oceny zachowań motorycznych dziecka, opracowane przez zespół Profesora Prechtla, pozwalające na opis dodatkowych zmiennych ruchowych dzieci, w wybranym wieku [29-30]. Pierwszy odnosi się do dziecka przedwcześnie urodzonego i w wieku terminu porodowego. Drugi- skupia się na motoryce niemowlęcia 3 - 5 miesięcznego. W skład arkusza MOS dla wieku 3-5 miesięcy, wchodzą następujące obszary: (1) obecność i jakość FMs, (2) obecność i typowość innych wzorców ruchowych, (3) obecność i typowość wzorców posturalnych, (4) adekwatność aktywności motorycznych do wieku, (5) jakość motoryki. Narzędzie ma czułość i swoistość na poziomie 70\%, wykazuje korelację z GMFCS [31]. Arkusze MOS są dobrym uzupełnieniem oryginalnej procedury GMA, pozwalają na statystyczną analizę działań dziecka i porównywanie wyników z innymi metodami pomiarowymi. Mogą też przewidywać, jak dziecko będzie się zmieniało w swojej trajektorii rozwojowej, we wczesnym okresie życia [32]

\section{Wczesna interwencja i GMA}

Doniesienia naukowe wskazują, że po urodzeniu, rozwój OUN, zależny jest od aktywności neuralnej kory ruchowej [33]. W tym kontekście, wczesne uruchomienie programu usprawniania dziecka, który będzie je angażował w interakcję z otoczeniem- wydaje się być sprawą zasadniczą [34-35]. Tzw. wczesna interwencja powinna być ukierunkowana, na wspomaganie procesów neuroplastycznych dziecka z jednoczesnym ograniczaniem negatywnych skutków atypowego rozwoju motorycznego na aparat ruchu [36]. Istnieje wiele podejść terapeutycznych, które 
proponują różnorakie rozwiązania. W celu weryfikacji skuteczności hipotez terapeutycznych, rodzi się potrzeba narzędzi oceniających ich skuteczność.

W literaturze można znaleźć kilka artykułów, skupiających się na potencjale GMA dla oceny i kontroli procesu usprawniania we wczesnej interwencji [37-40]. Publikacje te opisują różne grupy badawcze, w nietożsamych okolicznościach i poddawane niepodobnym działaniom terapeutycznym. Wziąwszy po uwagę ten fakt, nie jest zaskakującym, że wnioski końcowe badań także się nie pokrywają. Niemniej, niektóre doniesienia, sygnalizują, iż działanie fizjoterapeutyczne modyfikuje charakter, jakość motoryki GMs i to zarówno w wieku ruchów wijących jak i fidgety [38-39]. Z powodu prostoty, szybkości, nieinwazyjności i obiecujących danych wstępnych- GMA, w przyszłości może stać się istotnym elementem weryfikacji interwencji.

\section{PODSUMOWANIE}

Korzystanie ze skutecznych narzędzi oceny rozwoju noworodka i niemowlęcia, będą obniżały wiek rozpoznania i pozwalały na wdrażanie prawidłowej interwencji tam gdzie jest potrzebna. Wczesne usprawnianie dziecka, pozwoli na kształtowanie prawidłowego jego rozwoju i zapobiegnie utrwaleniu nieprawidłowych wzorców. General Movement Assessmnet (Metoda Prechtla) jest szybką, skuteczną metodą, umożliwiającą rozpoznanie nieprawidłowości w rozwoju dziecka.

\section{PIŚMIENNICTWO}

1. Hnatyszyn G.: Choroby ośrodkowego układu nerwowego. [w:] Szczapa J.[red.] Podstawy neonatologii. Wydawnictwo lekarskie PZWL, Warszawa 2008; 251-282.

2. Johnston MV.: Brain plasticity and its disorders.[w:] Swaiman `s Pediatric Neurology. Swaiman KF., Ashwal S., Ferriero DM., Schor N. [red]. Volum one, ELSEVIER Sauders,2012.

3. Prechtl HF.: Qualitative changes of spontaneous movements in fetus and preterm infant are a marker of neurological dysfunction. Early Hum Dev. 1990 Sep 23:151-158.

4. Prechtl HF.: General movement assessment as a method of developmental neurology: new paradigms and their consequences. The 1999 Ronnie MacKeith lecture. Dev Med Child Neurol. 2001; Dec 43: 836-842.

5. Einspieler C., Prechtl, H.F.R., Bos et al.: : Prechtl's Method on the Qualitative Assessment of General Movements in Preterm, Term and Young Infants. MacKeith Press: London, UK, 2004; pp. 1-104.

6. Einspieler C., Bos A.F., Libertus et al.: The General Movement Assessment Helps Us to Identify Preterm Infants at Risk for Cognitive Dysfunction. Front Psychol. 2016 Mar 22; 7: 406. doi: 10.3389/fpsyg.2016.00406.

7. Katz P.: Evolution of central pattern generators and rhythmic behaviours. Philosophical Transactions of the Royal Society B: Biological Sciences. 2016. 371.

8. Cioni G., Prechtl H.F.: Preterm and early postterm motor behaviour in low-risk premature infants. Early Hum Dev. 1990 Sep;23:159-919.

9. Prechtl, H. F. R.: Spontaneous motor activity as a diagnostic tool: Functional assessment of the young nervous system. A scientific illustration of Prechtl's Method. GM Trust, Graz, 1997.

10. Einspieler C., Prechtl H.F.: Prechtl's assessment of general movements: a diagnostic tool for the functional assessment of the young nervous system. Ment Retard Dev Disabil Res Rev. 2005; 11: 61-67.

11. Einspieler C., Peharz R., Marschik P.B.: Fidgety movements - tiny in appearance, but huge in impact. J Pediatr (Rio J). 2016 May-Jun; 92(3 Suppl 1): 64-70.

12. Einspieler C., Marschik P. B., Prechtl, H. F.R.: Human motor behavior: Prenatal origin and early postnatal development. Journal of Psychology, 216(3), 147-153.
13. Ferrari F., Frassoldati R., Berardi A. et al.: The ontogeny of fidgety movements from 4 to 20weeks post-term age in healthy full-term infants. Early Hum Dev. 2016 Dec;103:219-224.

14. Dibiasi J., Einspieler C.: Can spontaneous movements be modulated by visual and acoustic stimulation in 3-month-old infants? Early Hum Dev. 2002 Jun; 68(1): 27-37.

15. Dibiasi J., Einspieler C.: Load perturbation does not influence spontaneous movements in 3-month-old infants. Early Hum Dev. 2004 Apr; 77(1-2): 37-46. Address: 10.1016/j.earlhumdev.2004.01.004.

16. Prechtl H.F., Einspieler C., Cioni G.et al. : An early marker for neurological deficits after perinatal brain lesions. Lancet. 1997 May 10; 349(9062): 1361-1363.

17. Ferrari F., Cioni G., Einspieler C. et al.: Cramped synchronized general movements in preterm infants as an early marker for cerebral palsy. Arch Pediatr Adolesc Med. 2002 May;156(5): 460-467.

18. Romeo D.M., Guzzetta A., Scoto M. et al.: Early neurologic assessment in preterm-infants: integration of traditional neurologic examination and observation of general movements. Eur J Paediatr Neurol. 2008 May; 12(3): 183-189.

19. Burger M., Louw Q.A.: The predictive validity of general movements-a systematic review. Eur J Paediatr Neurol. 2009 Sep; 13(5): 408-420.

20. Einspieler C., Yang H., Bartl-Pokorny K.D.et al.: Are sporadic fidgety movements as clinically relevant as is their absence? Early Hum Dev. 2015 Apr;91(4): 247-252.

21. Cioni G., Belmonti V., Einspieler Ch.: Early Diagnosis and prognosis in cerebral palsy. In: Shepherd R, ed. :Cerebral Palsy in Infancy. Oxford, England: Elsevier; 2014: 177-185.

22. Fjørtoft T., Einspieler C., Adde L.et al.: Inter-observer reliability of the "Assessment of Motor Repertoire--3 to 5 Months" based on video recordings of infants. Early Hum Dev. 2009 May; 85(5): 297-302.

23. Mutlu A., Einspieler C., Marschik P.B.et al.: Intra-individual consistency in the quality of neonatal general movements. Neonatology. 2008; 93: 213-216.

24. Støen R., Songstad N.T., Silberg I.E.et al.: Computer-based video analysis identifies infants with absence of fidgety movements. Pediatr Res. 2017 0ct; 82: 665-670.

25. Adde L., Yang H., Sæther R.et al : Characteristics of general movements in preterm infants assessed by computer-based video analysis. Physiother Theory Pract. 2018 Apr;34: 286-292.

26. Cioni G., Bos A.F., Einspieler C.et al.: Early neurological signs in preterm infants with unilateral intraparenchymal echodensity. Neuropediatrics. 2000 0ct; 31: 240-251.

27. Guzzetta A., Pizzardi A., Belmonti V., et al: Hand movements at 3 months predict later hemiplegia in term infants with neonatal cerebral infarction. Dev Med Child Neurol. 2010 Aug;52(8): 767-772.

28. Einspieler C., Cioni G., Paolicelli P.B., et al: The early markers for later dyskinetic cerebral palsy are different from those for spastic cerebral palsy. Neuropediatrics. 2002 Apr;33: 73-78.

29. Ferrari F., Cioni G., Prechtl H.F.: Qualitative changes of general movements in preterm infants with brain lesions. Early Hum Dev. 1990 Sep; 23: 193231.

30. Örtqvist M., Einspieler C., Marschik P.B., et al.: Movements and posture in infants born extremely preterm in comparison to term-born controls. Early Hum Dev. 2021 Mar; 154:105304.

31. Bruggink J.L., Cioni G., Einspieler C., et al.: Early motor repertoire is related to level of self-mobility in children with cerebral palsy at school age. Dev Med Child Neurol. 2009 Nov; 51: 878-885.

32. Einspieler C., Marschik P.B., Pansy J., et al.: The general movement optimality score: a detailed assessment of general movements during preterm and term age. Dev Med Child Neurol. 2016 Apr; 58: 361-368.

33. Novak I., Morgan C., Adde L., et al.: Early, Accurate Diagnosis and Early Intervention in Cerebral Palsy: Advances in Diagnosis and Treatment. JAMA Pediatr. 2017; 171: 897-907.

34. Eyre J.: Corticospinal tract development and activity dependent plasticity. In: Shepherd R, ed.: Cerebral Palsy in Infancy. Oxford, England: Elsevier; 2014: 53-66.

35. Martin J.H., Chakrabarty S., Friel K.M.: Harnessing activity-dependent plasticity to repair the damaged corticospinal tract in an animal model of cerebral palsy. Dev Med Child Neurol. 2011 Sep;53 Suppl 4(Suppl 4): 9-13. 36. Shepherd R.B., ed.: Cerebral Palsy in Infancy: Targeted Activity to Optimize Early Growth and Development. Oxford, England: Elsevier Health Sciences; 2014. 
36. Fjørtoft T., Ustad T., Follestad T., et al.: Does a parent-administrated early motor intervention influence general movements and movement character at 3months of age in infants born preterm? Early Hum Dev. 2017; 112: 20-24.

37. Soloveichick M., Marschik P.B., Gover A.,et al: Movement Imitation Therapy for Preterm Babies (MIT-PB): a Novel Approach to Improve the Neurodevelopmental Outcome of Infants at High-Risk for Cerebral Palsy. J Dev Phys Disabil. 2020;32(4):587-598.

38. Sokołów M., Adde L., Klimont L., et al.: Early intervention and its shortterm effect on the temporal organization of fidgety movements. Early Hum Dev. 2020 Dec; 151: 105197.

39. Ma L., Yang B., Meng L., et al.: Effect of early intervention on premature infants' general movements. Brain Dev. 2015 Apr; 37: 387-393. 